\title{
A Companhia de Reis Santa Luzia, Londrina/PR: considerações acerca do catolicismo tradicional popular brasileiro e o papel de seus mestres-rituais
}

\author{
The Companhia de Reis Santa Luzia, Londrina/PR: \\ considerations about of the popular Catholicism traditional \\ Brazilian and the sheet of him rituals-masters
}

\author{
André Camargo Lopes*
}

\begin{abstract}
RESUMO
Este artigo é resultado de uma série de entrevistas realizadas com o mestreembaixador Antonio Francisco, da Companhia de Reis Santa Luzia, assim como o trabalho de observação participante da jornada de Reis 2007/2008 que realizamos junto a Companhia pelos bairros do município de Londrina/PR. Temos por objetivo apontar neste artigo alguns elementos que caracterizam o catolicismo tradicional popular brasileiro, em seu aspecto cultural, configurando a partir desta perspectiva a formação de seus mestres-rituais e a estrutura ritualística e organizacional da jornada de Reis dentro deste universo cultural.
\end{abstract}

PALAVRAS-CHAVE: catolicismo tradicional; KEYWORDS: traditional Catholicism; ritualsmestres-rituais; religiosidade popular.
ABSTRACT

This article is result of the one a sequence of interviews achieved with the master ambassador Antonio Francisco, of the Companhia de Reis Santa Luzia, thus as the work of the participant observation of the journey of Kings 2007/ 2008 how achieved close the Company in the district of a city the municipality of Londrina/ PR. Have for objective to sight in the paper something's elements how defined the popular Catholicism traditional Brazilian, in your expression cultural, configured across of this perspective the formation of yours rituals-masters and the structure ritualistic and organizational the journey of Kings of this cultural universe.

Forma de expressão de um catolicismo tradicional popular brasileiro, a Folia de Reis tem na tradição oral o movimento da transmissão de sua prática ritualística e simbólica. Todavia devido ao seu próprio mecanismo de transmissão cultural, a tradição se estende a grupos minoritários de contemporâneos que procuram compartilhar suas lembranças e de quem podem aprender sobre eventos passados não vividos pessoalmente. A construção do sentido da festa e de seus símbolos se dá como um fenômeno de colagens, em que elementos que perdem no tempo a sua autoria, têm seus fragmentos colados as interpretações dos agentes rituais que a vivenciam, dinamizando e atualizando os seus significados dentro do grupo social, demarcando a individualização criativa que tem no grupo o reconhecimento coletivo e a

\footnotetext{
Mestre em História Social pela Universidade Estadual de Londrina (UEL) /Brasil.
} 
aceitação.

Para a compreensão deste universo cultural, são os relatos orais e a pesquisa participante ferramentas metodológicas de grande abrangência qualitativa. Sendo os relatos orais extraordinárias fontes de análise, ao procurarmos compreender nos agentes sociais a complexidade das relações que estruturam o fenômeno histórico-social a partir de seu cotidiano. Os relatos sobre o passado englobam explicitamente a experiência subjetiva dos agentes sociais, revelando heranças culturais num processo de reconstrução do passado a partir de um lugar presente que estrutura a narrativa (AMADO, 2002).

Neste sentido, a Folia de Reis como uma manifestação do imaginário católico tradicional popular, corresponde a uma destas múltiplas e livres interpretações dos escritos bíblicos, divulgados nas missas dominicais, e lidos a partir do referencial social e cultural de seus praticantes. Assim como as demais manifestações da religiosidade popular o mestre-ritual (que se configura na imagem do mestre-embaixador) é um substitutivo do sacerdote oficial, está no meio social dos demais agentes, e é por estes legitimado como conhecedor dos segredos da fé.

Acerca deste tema, partimos do referencial levantado por Brandão (1981: 141) em seus estudos sobre a constituição da religiosidade popular, afirmando que dentro dos diversos núcleos sociais por onde transitam estes agentes sociais, as práticas religiosas são um catalisador da identidade social. Ou seja, é a partir de uma relação direta do agente com o sagrado, seja esta relação mediada ou não pela presença de algum santo de devoção que os agentes sociais, em seu momento de fé, solidificam suas crenças, compartilhando-as, podendo vivenciá-las de forma ativa: orando, dialogando, assistindo as programações de rádio e televisão voltadas a sua profissão de fé. Esta ativação do sujeito religioso promove a construção de uma identidade que transcende os limites dos espaços individualizantes, coletivizando-os em rituais festivos que celebram entre os participantes o contrato de fé.

\section{A Folia de Reis dentro da tradição do catolicismo tradicional popular brasileiro.}

As Companhias de Reis se caracterizam por serem grupos peditórios de cantores e instrumentistas, que percorrem as áreas periféricas de algumas 
cidades em diversas regiões do Brasil, visitando as casas de moradores devotos, levando-lhes a benção dos Três Reis Santos e anunciando o nascimento de Jesus.

A Companhia que foi o foco de nossas observações sai pelos bairros periféricos da cidade de Londrina-PR. ${ }^{1}$ Composta por treze integrantes, é liderada por mestre Antônio, um senhor aposentado (que na vida já foi lavrador, servente de pedreiro e zelador em escolas do município). A simplicidade com que este mestre-embaixador explica como começou a ser "agente da fé" (BRANDÃO, 1981: 152) ${ }^{2}$ ao "tirar sua bandeira",3 reflete as características de seu ritmo de vida, assim como a estrutura viva de um catolicismo tradicional popular nas práticas devocionais católicas no espaço urbano contemporâneo. Pois esta posição de agente da fé se mistura no cotidiano deste senhor, que a vivencia em suas atividades seculares de trabalho e de participação em outros setores da vida social. De modo geral, este agente é decorrente de um núcleo social católico, cujas regras da vida comunitária possibilitaram a prescrição das condições de acesso ao saber religioso que promovem uma acessibilidade de descendência. Esta perspectiva de "descendência" é constatada por Brandão em seus estudos acerca da formação dos mestres-rituais no catolicismo popular, o autor afirma que entre os "mestres católicos" são respeitados os direitos de descendência, principalmente os dos mestres e chefes de grupos rituais, como as Companhias de Reis, em que filhos e netos, via de regra, aprendem com pais e avós a quem servem de auxiliares durante estágios de iniciação; “(...) convocam os seus filhos homens, desde crianças, para ocuparem cargos de trabalho ritual em seus grupos e colocam sobre eles a esperança de continuidade do 'terno', 'companhia' ou 'turma' depois de sua velhice ou morte” (BRANDÃO, 1985: 155).

O conhecimento religioso deste mestre ritual do catolicismo tradicional popular é moldado dentro de um sistema cultural (no caso do mestre-ritual abordado é o meio rural o seu núcleo formador), refletindo uma visão de mundo

\footnotetext{
1 O espaço de atuação da Companhia concentra-se na região norte do município, nos conjuntos habitacionais dos quais todos os integrantes são moradores.

2 De acordo com Brandão (1985), dentro do campo religioso popular, os agentes da fé, são "especialistas" que agenciam a mediação religiosa, que sabem dizer mais palavras e produzir melhor os atos rituais bons para colocar o fiel ao alcance de algum ser de crença religiosa.

3 Tirar a bandeira é uma forma de expressão utilizada pelos embaixadores para se referir ao tempo de jornada de suas bandeiras, ou seja, neste sentido, tirar a bandeira estaria associado à processualidade ritualística que envolve colocá-la em giro.
} 
muito própria deste agente acerca do imaginário religioso, estabelecendo os seus códigos familiares e sociais que incorporam elementos fragmentados da História Sagrada, da doutrina e das regras das práticas devocionais da Igreja Católica. O sentido no qual este agente apresenta a tradição da Folia de Reis, se confunde com o universo da educação familiar, via de acesso e formação à tradição, que constitui não só um aspecto do universo da vida religiosa deste agente, mas também, um espaço de abrangência e sociabilidade.

$\mathrm{Na}$ constituição do catolicismo tradicional popular brasileiro, este condicionante existencial em suas dimensões de sociabilidade acaba por ser um elemento determinante nas práticas religiosas de uma legião de fiéis, caracterizando um catolicismo doméstico e devocional, ministrado pelos próprios praticantes. A religiosidade popular e todas as formas decorrentes desta relação com o sagrado está associada aos problemas do cotidiano dos agentes sociais, gerenciando muitas vezes todos os atos de suas vidas. Neste sentido, o cotidiano se apresenta como dominado por influências do "sobrenatural" que se refletem não só nos hábitos da vida religiosa como nos atos da vida material.

Por razões epistemológicas, os termos religiosidade popular e catolicismo tradicional popular brasileiro, não podem ser considerados em nossa abordagem como sinônimos, tendo em vista que o primeiro revela um campo mais amplo das práticas e vivências da fé no cotidiano do imaginário popular brasileiro. Reflete comportamentos de trânsito entre diversas matrizes religiosas que povoam nosso universo cultural, o que possibilita à luz da Antropologia, uma compreensão atual deste quadro, levantado a partir do Censo 2000, posto em relevo a matriz histórica e religiosa brasileira.

O termo "catolicismo tradicional popular brasileiro" utilizado em nossas reflexões promove uma projeção historiográfica ao mesmo tempo em que antropológica acerca de um modelo de vivência religiosa enraizada em um universo simbólico estruturalmente medievalizada e pré-tridentino. Estruturamos nossa discussão acerca deste tema a partir de dois pressupostos teóricos que fixam no catolicismo uma tipologia a partir da vivência religiosa de seus agentes.

Em artigo publicado na Revista Eclesiástica Brasileira no ano de 1968, o Pe. José Comblin, a partir dos estudos de Thales de Azevedo (1966), propõe 
uma tipologia historiográfica que contribui para a compreensão da estrutura da vida religiosa católica e suas diversas vivências em relação à experiência religiosa no Brasil do século XX. Dentre as quatro bases levantadas pelo autor, é o Catolicismo medieval, que contribui para a estruturação de um catolicismo tradicional e popular. $\mathrm{O}$ autor reconhece o trânsito na vivência religiosa destes agentes, não apontando para uma rigidez e imutabilidade deste quadro, todavia, é na matriz medieval do catolicismo praticado no Brasil que encontramos suas divisões epistemológicas: as vertentes milagrosa e penitencial. Sendo o primeiro um modelo de catolicismo remanescente da expansão católica pela Europa, pautado no culto aos santos e ao poder milagroso dos mártires. No Brasil, como afirma o autor, alguns elementos de cunho sociológico contribuíram para a transferência e a manutenção desta vivência religiosa de forma quase arcaica. $\mathrm{O}$ isolamento de várias populações no interior brasileiro, assim como, as altas taxas de analfabetismo nestas regiões, além, da falta de sacerdotes possibilitaram o culto ritualístico popular4. Este perfil de vivência da fé, mesmo urbanizado e próximo às estruturas diocesanas da Igreja, se mantém pautado numa prática tradicional nas muitas famílias de migrantes que vivenciaram os grandes deslocamentos internos no Brasil entre as décadas de 1960 a 1990. Segue-se o mesmo perfil deste catolicismo milagroso, o catolicismo penitencial, pautado na auto-flagelação dos agentes e reforçado por períodos de nossa história cultural e religiosa, na qual, no imaginário popular estas passam a serem reconhecidos socialmente como atos de santidade ou de grandeza espiritual (COMBLIN, 1968: 57). 5

Numa perspectiva mais ampla acerca desta relação entre o catolicismo e a formação da sociedade brasileira (superando a definição de popular -arraigada em classe social- definida por Comblin), a historiadora Célia Maia Borges, vê no termo "tradicional", a expressão mais eficaz para definir o modelo de

4 Devemos ressaltar que o autor escreve tendo como referencia sociológica o seu tempo, neste sentido, temos um Brasil em processo de urbanização, porém, com um grande contingente populacional vivendo no campo.

5 Para Comblin, grande parte da mensagem penitencial foi oficializada pela Igreja ocidental, o que deu lugar à sua transformação sacramental, com a confissão freqüente e a lei da confissão anual, ao desenvolvimento extraordinários das indulgências e de todas as práticas penitenciais. Foi, também o princípio do moralismo, de uma certa religião para o povo. Neste sentido, os pregadores franciscanos e dominicanos fizeram de suas missões verdadeiros processos desta vivência do catolicismo. Anunciavam o fim do mundo e o castigo. Denunciavam os vícios, o luxo, a vida e a diversão. Apresentavam a confissão dos pecados e a conversão como remédio que aplaca a ira de Deus. 
catolicismo que se instalou no Brasil, contrapondo em suas práticas e estrutura ao Catolicismo Tridentino (2005: 28).6 Este catolicismo tem por principal característica o modo de organização, assim definido, como sendo um sistema de organização de leigos, simbolicamente estruturado em um universo religioso medieval e definido estruturalmente pela organização social brasileira pautada nas formações das grandes famílias patriarcais de senhores rurais. Para tal, cabe ressaltar que Borges credita a organização social brasileira, a possibilidade desta vivência do catolicismo, não desconsiderando quão problemática é esta qualificação quando se tem em mente a participação dos religiosos no processo de colonização brasileira.

É nesta perspectiva histórica que temos o catolicismo praticado no Brasil como luso-brasileiro, leigo, medieval, social e familiar. Isso, porque este é uma herança de um catolicismo impregnado de práticas mágicas, tendo a população um papel central em sua transplantação. Enquanto que na Europa da Idade Moderna ocorria o processo de urbanização, o Brasil mantinha-se por um longo período, predominantemente rural, com um universo religioso leigo apoiado na família patriarcal.

\section{A Folia de Reis: manutenção de uma tradição popular.}

A Folia de Reis é uma das festas que celebram o período do Natal dentro da tradição católica tradicional popular brasileira, elemento cultural decorrente do catolicismo português, a tradição, como afirmam os folcloristas, foi trazida para o Brasil no início da colonização portuguesa. Se junta a esta, outras festividades de cunho popular que revelam a afirmação de uma identidade festiva dentro das práticas católica na sociedade brasileira, dividindo sua incidência de acordo com as localidades de origem.

De acordo com o antropólogo Carlos Rodrigues Brandão, em Portugal a Folia foi uma dança profana e popular, popularizada sobretudo durante os séculos XVI e XVII, onde homens vestidos à "portuguesa”, dançam com guizos nos dedos, gaitas e pandeiros, girando e pulando ao redor de um tambor. Esta dança chega ao Brasil, já incorporada aos repertórios de dança de salão, e mais

\footnotetext{
6 Borges afirma que o termo tradicional foi utilizado por uma linha de pesquisadores da religião, para definir a vivência religiosa da fé católica que se contrapunha em suas práticas ao catolicismo reformado pelos ideólogos do Concilio Trindentino.
} 
tarde, assumem um caráter mais grave ao serem incorporadas, juntamente com cantos e danças camponesas, aos ritos da Igreja (1985: 141).

No Brasil, a decorrência destas festividades está ligada à representação de pequenos autos, dramas de fundo devocional popular que, transformam-se em uma afirmação da identidade cultural de grupos sociais, ao representarem nesses autos, a sua relação com o universo religioso. Associados ao calendário litúrgico, estas festividades do ciclo do Natal, ao longo da Idade Média formavam rituais solenes e demorados, o que de acordo com Brandão era:

\begin{abstract}
Um teatro cristão ao mesmo tempo litúrgico e catequético nasceu no interior dos templos e, no século XI, possuía já um lugar e uma estrutura claramente definidos dentro de cerimônias propriamente litúrgicas. Solenes ofícios das grandes missas natalinas misturavam anjos, pequenos pastores e personagens da Sagrada Família em piedosas e alegres encenações dos acontecimentos da noite de Natal. Com base no Evangelho de um primeiro drama, o Officium Pastorum foi criado e colocado junto ao Intróito da Missa de Natal.

Ele chega ao século XIII acrescentado de mais anjos e dos bichos piedosos da manjedoura. Tempos mais tarde os festejos do nascimento de Jesus se prolongam até à festa de Epifania, 12 dias após a do Natal. Muito embora os acontecimentos posteriores ao próprio nascimento de Cristo fossem litúrgica e eclesiasticamente menos importantes, o fato é que eram mais dramáticos. Pensemos na viagem aventureira dos Três Magos popularmente dramáticos. Pensemos na viagem aventureira dos Três Magos do Oriente, na Matança dos Inocentes, na Fuga da Sagrada Família. (BRANDÂO, 1985: 141-142)
\end{abstract}

Com o acréscimo de novos personagens ao auto, Herodes, os soldados, os três visitadores passam de personagens secundários a elementos principais da celebração. A nova seqüência de festejos estende até seis de janeiro as celebrações do ciclo natalino e acaba por constituir um segundo drama litúrgico, incluindo no interior das cerimônias oficiais, o Officum Stelae.

No Officum Stelae, embora o Menino Jesus permaneça como a principal figura de referência, este deixa de ser o personagem central do drama, posto este que passa a ser ocupado pelos Três Magos que repartem com Herodes as cenas principais. Acerca destes autos litúrgicos no Brasil, são os jesuítas que em suas reduções irão introduzi-los como ferramentas catequéticas.

Em seus estudos sobre a música popular brasileira, Tinhorão afirma que eram as festas religiosas, dentre elas, o Natal, momentos que transformavam as igrejas em teatro, para a representação de autos alusivos ao nascimento de Cristo. Autos e dramas litúrgicos, que faziam traduzir aos diferentes grupos étnicos que compunham os espaços das reduções, onde os próprios agentes do espaço encenavam, cantavam e dançavam nos momentos de celebração destas 
encenações religiosas (1972).

Silvio Romero em texto de 1879, ao se referir as festas populares no Brasil, apontava duas espécies: as de igrejas (festa de igreja é um termo que popularmente procura definir o sentido sacro dentro da festividade) popularizadas e as exclusivamente populares. Em suas palavras as primeiras “(...) são festas de órgãos, em que o povo toma parte com folganças especiais" (ROMERO apud CASCUDO, 2003: 287); enquanto que a segunda espécie de festas, “(...) pertencem as festas gerais de Natal, Ano Bom, Reis, São João, São Pedro, Espírito Santo, com seu cortejo de chibas, sambas, reisados, cheganças, etc.", definindo os espaços pela participação ativa dos agentes populares.

Na cultura Folclórica do século XIX, muitos estudiosos da cultura popular brasileira relataram suas observações acerca destas festividades populares, tendo, como referência, um método descritivo, impressionista, quase que literário. Numa perspectiva memorialista, estes autores registraram figuras, festas, tipos de ruas, revivendo-as em suas narrativas, material, este, que serve como substrato para o levantamento do comportamento popular nesses períodos festivos, revelando ao mesmo tempo a interpretação do universo simbólico litúrgico, pelos diversos grupos populares, dentre eles o dos próprios autores.

Em suas observações acerca das festividades populares, o folclorista Morais Filho relata em suas observações na Bahia e no Rio de Janeiro, no final da segunda metade do século XIX, outros autos como o Boi Bumba, as Pastoris, e as cheganças que em suas palavras, representavam momentos de atenuação da realidade social:

Na Bahia, os presepes, os bailes de pastores e os descantes de Reis prolongam-se até ao carnaval. - É o tempo das mangas, das músicas e das mulatas!

Dessa noite em diante, os cantores de Reis percorrem a cidade cantando versos de memória e de longa data.

Esses ranchos compõem-se de moças e rapazes de distinção; de negros e pardos que extremam, às vezes, e se confundem comumente.

Os trajes são simples e iguais calça, paletó e colete branco, chapéu de palha ornado de fitas estreitas e compridas, muitas flores em torno, etc.; precedendo-se na execução habilíssimos tocadores de serenatas.

(...) Os ranchos, ao fogo dos archotes, ao som das flautas e violões, dos cavaquinhos e pandeiros, das cantorias e castanholas, dirigem-se: ao presepe da Lapinha, às casas conhecidas em que se festeja o Natal, ou tiram Reis à aventura do acaso. (MORAIS FILHO, 1946: 105)

Em trabalho de 1879, Celso de Magalhães, ao se referir às festas de Natal maranhenses e na Bahia, aponta nestas o caráter festivo que as remete às 
janeiras portuguesas, incorporando ao calendário litúrgico a relação de identificação que o povo mantém com a festa:

\begin{abstract}
As festas do Natal, Ano Bom e de Reis (“Janeiras") são as mais populares em nossas províncias, e cremos que muito semelhantes às de Portugal. Pelo menos o sentido das cantigas que nelas se cantam é o mesmo que o das portuguesas. Nas províncias do Maranhão e da Bahia, onde nos parece ter encontrado mais o espírito popular nessas festas, elas são feitas de um modo que alegra o coração e faz bem à alma. Os bandos de pastores, uma lembrança talvez do teatro hierático, o canto dos Reis, os bailes e bandos de S. Gonçalo, outro arremedo de antigos Autos, as festas de arraial, do Espírito Santo, tudo isso é de um sabor tão campestre, tão do povo, que encanta.

No Maranhão e na Capital da Bahia a cantiga de Reis já intrometeu-se pela sociedade abastada e é uma diversão da alta burguesia.

Não é raro verem-se, em véspera de Reis, bandos de moços e raparigas que se reúnem, com uma orquestra mais ou menos completa, na cintilação das jóias e das ricas toilettes, no gorjeio das risadas cristalinas, no tiroteio dos bons ditos, no cruzar dos olhares, na familiaridade franca e honesta do parentesco, da amizade, da convivência, não é raro ver-se essa sociedade parar a uma porta fechada, erguer as vozes, casadas, entoar uma toada monótona em que festejam o nascimento de Cristo e os amores maternos de Maria.

A porta abre-se então de par em par e os cantores entram, numa onda colorida e perfumosa, no meio dos risos de felicitações. Uma mesa acha-se sempre profusamente servida. Os donos da casa buscam por todos os meios agradar às visitas e estas saem finalmente, para irem à outra casa, e assim correm três a quatro numa noite. Na ultima casa visitada acaba-se a festa com dança. (MAGALHÃES apud CASCUDO, 2003: 263-264)
\end{abstract}

Em ambos os autores a narrativa verte para um universo festivo mediavalizado onde o elemento sagrado e o profano das festas e das danças se entrelaçam. Remetendo às janeiras portuguesas, Câmara Cascudo afirma que tais festividades são correntes já no século XIV fazendo-se presente nos folguedos populares portugueses. Estas festividades correspondiam a grupos que a partir da noite de natal passavam a percorrer as vizinhanças do campo, aldeias ou cidades, cantando e tocando temas de louvor ao nascimento do Deus Menino. O rito destas festividades envolvia um movimento de reciprocidade entre os foliões e os anfitriões das residências visitadas, em que a consagração da casa com as cantigas, tinha como agrado, bebidas e alimentos (CASCUDO, 2001: 289).

É nesta circularidade interpretativa entre os textos bíblicos e sua discursividade institucional (dramas, cânticos, autos), a receptividade, interpretação e prática religiosa e devocional dentro do imaginário social que se situa a produção das festividades religiosas no Brasil, dentro de um movimento interpenetrativo. O historiador italiano Carlo Ginzburg, afirma a existência de uma circularidade na relação entre o universo cultural "hegemônico" e o 
"subalterno", que gera "(...) um influxo recíproco entre cultura subalterna e cultura hegemônica" (1987: 20). Nesta perspectiva, Ginzburg se pergunta até que ponto os elementos da cultura hegemônica, encontrados na cultura popular são frutos de uma aculturação, e não ao contrário, no qual o imaginário popular tende a deformar o discurso hegemônico o conduzindo a um universo imaginário familiar.

Carlos Rodrigues Brandão, ao definir em seus estudos acerca da cultura popular brasileira, a localização dos "fatos folclóricos", afirma que estes fatos são elementos produzidos e absorvidos pelo grupo social de praticantes, justamente por que é aceito por ela e incorporado ao seu repertório de maneira de "pensar, sentir e agir de um povo, preservados pela tradição" (BRANDÃO, 1984).

Este processo de apropriação e adequação dos discursos culturais e religiosos ao cotidiano, possibilita aos agentes rituais, afirmarem a sua identidade, legitimando a mesma pela tradição que a normatiza. Neste sentido, a tradição é o referencial cultural destes agentes sociais e suas celebrações. Sztompka ao se referir a este conceito, define como base da tradição a relação entre o presente e o passado, em que por meio de formas materiais e ideais, ${ }^{7}$ as pessoas herdam crenças, conhecimentos e símbolos, bem como normas, valores e regras do passado (SZTOMPKA, 1998: 112). Tendo a Folia de Reis como um elemento catalisador deste mecanismo ideal da tradição, o passado mantém o diálogo com o presente através de pessoas que recordam seus fragmentos.

\section{Entre a tradição familiar e o contrato com o santo: a Companhia de Reis Santa Luiza}

Assim como outras práticas no catolicismo tradicional popular brasileiro, a Folia de Reis se organiza, em geral, em conseqüência de promessa, isto é um compromisso assumido por parte do embaixador (ou por algum parente ou amigo), no qual o mesmo se dispõe em tirar a sua bandeira por um período de sete anos a fim de agradecer a graça alcançada. Este contrato é o que caracteriza

\footnotetext{
7 De acordo com o autor os mecanismos materiais da tradição operam através da sobrevivência de objetos, artefatos e estruturas (casas, pontes, igrejas e monumentos) que, produzidos pelas gerações anteriores, envolvem as ações praticadas pela geração presente. Enquanto que o mecanismo ideal opera através de faculdades humanas de memória e comunicação.
} 
a bandeira da Companhia de Reis Santa Luzia, "(...) Eu saio simplesmente em devoção, eu não tenho mais promessa mais."; afirmação comumente utilizada por seu embaixador Antonio Francisco, para justificar a sua devoção e o giro de sua bandeira a pessoas externas a sua Companhia.

O embaixador ao se referir a origem de sua bandeira se remete há um tempo quase que incalculável que se perde em sua juventude. Diferentemente das outras Companhias que têm em suas bandeiras representados apenas a imagem da veneração aos Reis Magos, sua bandeira assim como o nome de sua Companhia destoa das demais, pois de acordo com o mesmo, a origem de sua bandeira está em sua devoção à Santa Luzia:

... Na Zona Norte, então em minha bandeira fica o retrato de Santa Luzia né? Todo mundo fala que Santa Luzia foi martirizada, ela teve sofrimento né? Porque no tempo do paganismo não era só é ... Todas as pessoas claro que tinha filhos bonito era mulher de reis sabe? Ficava de escrava, então teve muito sofrimento.

E nóis tava andando aí, com a fotografia aí, e a pessoa começou a criticá a gente né?

Eu deixei ele falá bastante. Eu falei “- Ocê sabe o segmento disso aí? Que em 1945 no final da Guerra quando a gente veio aqui para Rolândia que se chamava [Craviuna].

Então um fato aconteceu comigo. Cambé naquela época se chamava Nova [Danza], e então eu brincando num terreirão de café assim, né? De bola de borracha, eu cai e machuquei este assim [coloca a mão sobre o olho direito demonstrando o local da lesão]. De vez enquando lá em Cambé, ia lá um médico, que naquela época falou pro meu pai, pra minha mãe que não tinha mais jeito. (...) E naquela época era diferente, só tinha médico quem pagava IPI. Morria muita gente naquela época, que não tinha recursos.

Então pagou a primeira consulta, fez o exame, aí, meus olhos novamente do mesmo jeito. Aí deu que minha mãe ajoelhou e pediu que Santa Luzia ajudasse que eu não perdesse minhas vistas, que eu sempre ia sair em homenagem dela com louvor as crianças dando as pessoas uma festinha né? Daí eu sai sete ano. Eu até nem falo. Minhas filhas vêm de São Paulo e pergunta: “- Pai o senhor já não cumpriu a sua promessa?"

Eu saio simplesmente em devoção, eu não tenho mais promessa mais.

Neste sentido, entre o embaixador e a santa, estabelece-se uma postura ética em detrimento da concepção do milagre por parte da Santa, e do cumprimento da promessa por parte do embaixador, em que a vida religiosa deste será orientada através deste contrato estabelecido, podendo o milagre ser desfeito e o próprio punido pela Santa em caso deste não cumprir a sua parte do acordo.

Eu tava com quinze ano, quando eu tirei bandeira. Andei treis casa e meu zóio encheu de sangue. Ai, minha mãe (...) Naquela época a gente morava aqui ó. Perto de Jaguapitã.

Ai minha mãe falou que ia chamar um tal de Zé Baiano pra tira a bandeira. 
Ai foi à época de ... Da revelação né? Ela pediu pra mim ponhá uma vela, pegá uns gaio de arruda cortado e ponhá nas vista né? E rezá uma prece pra ela [Santa Luzia], ai, o solão quente rapaz, o cara chegou.

Andei treis casa debaixo do sol. Primeiro ano andei treis casa, daí começou duê. Duê. Ai os cara chegou: “- É o Toninho não vai. Não vai”.

Meus olho tava inchado, tudo borrifado. Mas eu não blasfemei. Ai eu peguei e falei: “-Ah, mãe, eu vou sim".

Ela disse: "-mas você não dormiu depois daquela hora". Mas já era noite ("-Você não dormiu") duendo, os zóio vermeio. Daí tornei passá aquilo na minha vista, e andei treis casa com os zóio duendo.

E tô ai até hoje, duvido que tenha pessoa que tem os olho melhor pra enxergar, graças... Criei meus filho tudo, e nunca na minha casa teve um filho com problema de vista.

Então. Uma água que eu tenho lá, eu posso tá com o maior problema, qualquer de coisa que tivé, aquela água é assim, eu bebo aquela água... Noutros pensamento né? Pra mim a fé em Deus é tudo pra mim.

A promessa, só que agora mesmo eu já não pago, eu saio em devoção pro que eu já não tenho promessa.

É devoção.

Podemos observar na fala que o não blasfemar reflete a confiança depositada na capacidade da santa, toda a fala parece construir um sentido moral para o milagre, o fato deste não ter sido concebido de imediato, exigindo o sacrifício por parte do devoto para cumprir a sua promessa, estabelecendo depois da concepção do milagre um vínculo de proximidade da santa com o devoto. Nesta relação de devoção, a bandeira da Companhia de Reis do embaixador Antonio Francisco, carrega consigo, uma miscelânea de santos de sua devoção (Nossa Senhora Aparecida; a Sagrada Família; Santa Luzia; os Três Reis Santos e mais recentemente a imagem de Santa Rita de Cássia), iniciando a sua jornada no dia de 13 de dezembro, dia de Santa Luzia, doze dias antes das demais Companhias.

Na sua composição atual, a Companhia de Reis Santa Luzia tem treze componentes, sendo cinco destes, mulheres que auxiliam no transporte das prendes e no coro da requinta. Os instrumentos são portados por sete dos oito homens que compõem a Companhia. De acordo com o embaixador, ocorre um trânsito constante de foliões em sua Companhia, tendo em vista (como ocorre em muitos casos), que os compromissos de trabalho impedem os foliões de acompanharem a jornada, afastando-os; ou em casos de falecimento. Neste sentido, ocorre uma reposição constante nestes "postos”, a inclusão de novos foliões a sua Companhia se dá através de convites por parte do embaixador, ou de algum outro folião.

Temos no perfil societal dos componentes da Companhia: aposentados, 
pedreiros, vigilantes, empregadas domésticas e donas de casa, além de um desempregado. A média etária de seus componentes não difere das demais, ${ }^{8}$ com foliões acima de cinqüenta anos de idade, católicos praticantes em sua maioria - percebemos a presença de foliões que transitam entre os grupos de Renovação Carismática Católica, Vicentinos e a Companhia de Reis.

Neste sentido, existe um trânsito constante entre a liturgia católica e as práticas ritualísticas que estruturam a Folia de Reis - assim, devemos notar a reprodução constante dos atos de novenas católicos nos momentos solenes do rito, como a saída da bandeira, os pousos de bandeira e o terço de chegada. Quanto à organização e à distribuição das funções destes na manutenção da Companhia, podemos notar que ocorre num quadro de permanência e tempo de atuação do componente junto ao grupo.

É notório que compete aos foliões permanentes, 9 a divisão das tarefas de controle da Companhia (a gerência e a tesouraria), enquanto que aos demais as funções estão atreladas somente à execução do rito. De acordo com o embaixador Antonio Francisco, o controle de uma Companhia de Reis é desgastante, cheio de conflitos internos que devem ser sanados na própria jornada, e é o embaixador quem decide o folião apto ou não a sair por sua bandeira, e também é ele o responsável direto pelo comportamento de seus foliões, tanto na rua quanto na execução ritual dentro das residências.

O organizar a Companhia, ensaiá-la, comprar o material necessário para a festa de saída de bandeira e de arremate, torna a divisão do trabalho de controle com os demais integrantes, indispensável. O gerenciamento do pessoal e o controle da arrecadação são distribuídos a dois integrantes de confiança do embaixador. A divisão destas funções não descentraliza o núcleo de controle da Companhia, pois todos os integrantes estão sujeitos ao controle do embaixador. É ele que ao longo da jornada, decide quando e como será utilizado o dinheiro arrecadado, e também é este em última instância que define as advertências a serem dadas a foliões que desobedecem as normas que regem a Companhia.

\footnotetext{
8 Atualmente dentro do município de Londrina existem apenas quatro Companhias de Reis, sendo que em 2007 apenas três sairam jornada. Todas apresentam uma proximidade de média etária muito próxima aos 55-60 anos de idade de seus integrantes.

9 Foliões que criaram um centro vínculo de fidelidade com a bandeira da Companhia, mantendo-se a essa ora por amizade com membros do grupo, ora por uma consciência de missão a ser cumprida.
} 


\title{
Preparações da Companhia para o início de jornada: observações sobre a preparação e saída de bandeira na jornada de 2007/8
}

A Companhia de Reis Santa Luzia promove a sua saída de bandeira no dia treze de dezembro, dia da santa padroeira do grupo, que tem sua imagem e nome registrado na bandeira do grupo e em seu uniforme. Neste dia parte do grupo se reuniu pelo período da tarde para a preparação da decoração da garagem da residência de um dos foliões onde seria rezado o terço de saída da bandeira. ${ }^{10}$ Correntes, bandeirinhas e flores ricamente trabalhadas pelos foliões foram sendo assentadas nas paredes externas da casa. No fundo da garagem um pequeno altar para a bandeira foi preparado, sobre uma toalha de renda, romãs foram enroladas em papel colorido e fechadas com fitas das cores das fitas da bandeira. Cada um dos integrantes trouxe a sua romã. Pois dentro da tradição religiosa que envolve o grupo, a romã simboliza os Santos Reis, como podemos ver na fala do embaixador Antonio Francisco:

\begin{abstract}
A Nossa Senhora representou dos dois lado, ela representou branca e negra. Entende? Ai, nos Monte Sinai, dava sete pé de romã e um jardim de flor. A outra Nossa Senhora que é a morena, ela pediu o Menino Jesus pra por no colo. Ai, quando Herodes chegou para conhecer o rei dos judeus para saudar, ele queria era matar né? $\mathrm{Ai}$ meteu a espada, o sol virou flor, e as romã saiu descendo.

As romã representa as sete chagas de Nosso Senhor Jesus Cristo. Por isso que as pessoas que puderem adquirir a romã, reze pelo menos uma dezena e oferece pra ele, e pede ao filho o que ele levou. Daqui ele levou ouro, incenso e mirra.
\end{abstract}

Num pedaço da mesma fita que envolve a romã foi escrito o nome da pessoa que estava fazendo o pedido aos Santos Reis, depois de cortada, foi colocada atrás da bandeira para cumprir o giro até o dia 6 de janeiro, data da chegada.

No início da noite, com a chegada do restante dos integrantes da Companhia, iniciou-se o ensaio das músicas do terço e de algumas embaixadas. O jantar teve início após as vinte horas, no fundo do quintal da casa do folião do terço, grandes panelas com frango, feijoada, macarrão e arroz permaneciam aquecidas sobre um fogão econômico (fogão a lenha). Todas as pessoas presentes foram convidadas a participar do jantar. Se organizando em um

\footnotetext{
10 As reuniões e saídas da bandeira, até o ano de 2005, eram realizadas no Conjunto Maria Cecília, na residência do violeiro Paulo. Porém, com o seu falecimento, a Companhia passou a se reunir no Conjunto Vivi Xavier, na casa de Dona Marinalva (integrante da Companhia), como aponta Dona Ilda, viúva do violeiro Paulo, e acompanhante da Companhia. Informação coletada em forma de anotação no dia 13 de dezembro de 2007.
} 
grande círculo, o grupo de pessoas ali presente começou o ritual do jantar. O embaixador puxou as orações, saudando os santos de devoção que reuniu os presentes, fez preces de forma espontânea, culminando em um Pai Nosso e uma Ave Maria. Dentro das formalizações de um rito católico popular, o grupo fez o fechamento das preces com pedidos de proteção à jornada, aos foliões e aos devotos, em seguida fizeram um cântico de agradecimento do alimento e se colocaram a jantar .

Após o jantar, deu-se início a uma queima de fogos, rojões anunciavam o terço e a saída da bandeira. Os rojões em meio à queima serviam de convite à vizinhança. ${ }^{11}$ Em seguida foi realizada uma saída simbólica da bandeira, pois esta só foi colocada em giro ${ }^{12}$ no sábado seguinte, dia em que a maioria dos foliões poderiam participar da jornada. A bandeira foi retirada da casa do terço para a casa de uma moradora próxima, local em que a bandeira ficou até o sábado de jornada. Todos os presentes no terço participaram do ritual de saída da bandeira que se iniciou com uma cantoria embaixada por mestre Antonio.

Findada a canção todos os participantes do ritual rezaram um Pai Nosso e uma Ave Maria. Cumprindo o comportamento ritual da saída bandeira, no portão de saída da casa, o embaixador a segurou para que todos os participantes do rito passassem por debaixo desta. Ao se aproximarem, os foliões beijavam e saiam por debaixo da mesma. Durante o trajeto da rua a Companhia manteve suas violas em silêncio, até a chegada na residência de pouso. Esta foi anunciada pelo Bastião, e a Companhia entrou cantando casa dentro:

\author{
Ai! "Santo" Reis aqui chegou \\ Ai! A estrela acompanhou \\ Ai! Vêm cantando os santos versos \\ Ai! Ao Menino Deus, Jesus \\ Ai! da "Virge" concebido \\ Ai! contra a dor que os "homem" têm \\ Ai! Ao Santo Reis faça um pedido \\ Ai! Mas peça a Deus e a "Virge" Maria \\ Ai! Santo Reis veio a essa Santa terra \\ Ai! com a Santa Estrela Guia \\ Ai! Pai, Filho e "Espirto" Santo \\ Ai! Na hora de Deus amém
}

\footnotetext{
11 A reza do terço não difere em quase nada dos terços praticados em novenas domésticas da Igreja Católica, sendo assim, um ritual muito próximo da liturgia católica oficial. Neste sentido, a reza do terço se estruturou da seguinte forma: Leitura dos mistérios -rezador; Reza da dezena do terço; Cânticos puxado pelo rezador e seguido por todos os presentes.

12 Colocar em giro é uma expressão usada pelos foliões para expressar a peregrinação da bandeira e da Companhia pelas ruas dos bairros visitados.
} 
Ao término da cantoria o embaixador encabeçou uma série de "vivas". Terminado o ritual, os foliões combinaram o horário e o local de encontro para o início do giro, em seguida todos se despediram e rumaram para suas respectivas residências, os foliões que moravam em bairro mais distante se dirigiram para o terminal urbano de transporte coletivo do bairro.

O giro da bandeira da Companhia teve início no sábado no início da tarde, tendo em vista que parte dos foliões trabalham e só poderiam estar presentes neste horário. Este fator também foi determinante na composição dos integrantes da Companhia ao longo da jornada, pois diferentemente dos momentos solenes do rito (terço de saída e chegada da bandeira), o giro sempre apresentou um número reduzido de foliões.

A embaixada de retirada da bandeira foi executada pelo contramestre Lauro, que ao longo da jornada as revezou com o embaixador Antonio Francisco e mestre Fidelcindo, ora este desenvolveu o papel de resposta (ou contramestre), ora embaixava, um revezamento necessário para o descanso das vozes ao longo da jornada, afirmou o mestre Antonio Francisco. A cantoria de saída, com mestre Lauro a frente dos versos ficou mais lenta, com uma toada mais chorosa.

Terminada a cantoria, outra vez, repetindo o gesto do dia anterior, o embaixador encabeçou uma salva de "vivas" junto aos presentes na casa. Ao terminarem a cantoria, a Companhia se despediu da dona da casa, colocando a bandeira em giro. Cumprindo o ritual de saída que se repetiu ao longo da tirada da bandeira em toda a jornada, os foliões se colocaram em fila para poderem saudá-la em sua saída, beijando-a e passando por baixo da mesma no portão de saída da residência que lhe serviu de pouso.

Ao longo da jornada, percebemos que o trajeto da Companhia foi determinado por um conjunto de residências que em anos anteriores a receberam, definindo assim, o itinerário a ser cumprido ao longo do dia. De acordo com o embaixador, este movimento da jornada se dá por dois motivos: o primeiro é simbólico, que ao repetirem a saga dos Três Reis Santos, a bandeira não deve voltar sobre o seu próprio caminho, o segundo está associado à ordem prática do próprio trajeto da jornada, ou seja, o trajeto é orientado pelo roteiro de residências que a receberam em anos anteriores.

Esta estrutura de peregrinação do rito pode ser dividida em dois padrões 
de jornada que se orientam entre as casas de pouso e as casas de giro, construindo sempre um caminho contínuo para a bandeira sem haver cruzamento ou retorno da mesma. Este trajeto possibilita a visualização de dois padrões da estrutura de giro:

Saída de manhã:

POUSO DE JANTA $\longrightarrow$ giro $\longrightarrow$ POUSO DE ALMOÇO $\longrightarrow$ giro $\longrightarrow$ POUSO DE JANTA

Este primeiro padrão ocorre quando a Companhia faz acordos de casas de almoço, então o giro da bandeira é tirado pelo período da manhã, e todo o trajeto desta neste período se destina a rumar para esta residência. ${ }^{13}$

Saída no período da tarde:

POUSO DE JANTA $\longrightarrow$ giro $\longrightarrow$ POUSO DE JANTA

A falta de casas disponíveis para servirem de pouso de almoço, associada a dois outros elementos determinantes na definição do período de tirada da bandeira -as altas temperaturas e o clima chuvoso do mês de dezembro, e a média de idade avançada na Companhia- possibilitaram um desenho da jornada que se restringia ao período vespertino, na grande maioria dos dias de peregrinação. ${ }^{14}$

\section{Os pousos da Bandeira: a casa de pouso de janta e a casa de pouso de almoço.}

Diferentemente das abordagens das Companhias que saem em regiões rurais, esta não pousa na casa e sim a bandeira e os instrumentos que simbolicamente simulam a presença dos foliões na casa de pouso de janta. Em sua chegada a uma casa de pouso onde foi acordado com o dono da residência que seria servido o jantar aos foliões e a bandeira receber pouso, a Companhia

\footnotetext{
13 As jornadas com tirada de bandeira pelo período da manhã foram poucas, concentrando-se mais especificamente nos finais de semana, dias em que os foliões das casas (a alguns integrantes da Companhia) não estão trabalhando, o que torna possível a visita da bandeira e o pouso de almoço.

14 A bandeira quase sempre era retirada da casa de pouso após as quinze horas. Este desenho da jornada se fixou em um trajeto de uma casa de pouso de janta a outra.
} 
chegou se anunciando, o pandeirista batia em seu instrumento anunciando a chegada dos foliões. A dona da casa estava à porta, e de imediato a recebeu, conduzindo a bandeira para o interior de sua residência, deixando-a em repouso sobre sua cama. Em meio a saudações e justificativas do atraso, a Companhia executou uma cantoria de embaixadas de mestre Antonio Francisco, agradecendo e ao mesmo tempo abençoando a janta oferecida pela família:
Ai essa casa é Sagrada
Ai é de um filho de Maria
Onde tem uma Santa Ceia
Ai uma ceia dada por Deus
Ai são os devotos de Santa Rita
Aqui nos "trais" a Estrela Guia
Ai quando "nóis" desencarnar
Os Santo Reis vai encontra
Pai, Filho e "Espirto" Santo
Na hora de Deus amém.

Em seguida retomaram-se os "vivas" celebrando o dono da casa e os Santos Reis e os outros santos que estão na bandeira. O embaixador puxou a oração, neste momento todos se colocaram ao redor da mesa, colocando-se a comerem após uma última salva de "vivas" desta vez puxada pelo Bastião da Companhia.

Após a janta, os foliões conferiram à arrecadação do dia, parte do dinheiro ficou com a tesoureira do grupo para ser usado na festa, e parte foi destinada ao pagamento do transporte coletivo dos foliões, pois estes já estavam rumando para suas residências. De acordo com os mesmos, a tradição exige que eles pousem juntos com a bandeira, porém, por estarem dentro do espaço urbano, os compromissos com o trabalho e a família além da distância entre a casa de pouso e suas residências não serem muito grandes, optam por retornarem, voltando somente no dia seguinte para a retomada da jornada ${ }^{15}$.

A retirada da bandeira da casa de pouso envolveu toda uma ação ritualística de agradecimento e partida. Posicionada diante da porta da residência a bandeireira da Companhia a deixa em posição que todos os foliões ao iniciarem seu dia de jornada possam beijá-la e passar por baixo desta. Neste

15 De acordo com os estudos de Castro e Couto, com referência nesta nossa abordagem, ao visualizarem a entrada da tradição de Reis dentro do espaço urbano fluminense, já ao longo dos anos 50 (jornada 52/53 e jornada 53/54), apontaram que ocorreram com as Companhias algumas adequações acerca da jornada registrando a seguinte constatação: “(...) Parece que, no interior, a folia passava todo o tempo da jornada pelas estradas, cantando e folgando em casas amigas, em constante peregrinação. Na região estudada, porém, as folias saem apenas aos sábados, domingos e feriados, comparecendo os foliões, normalmente, ao trabalho, nos demais dias do período”. CASTRO e COUTO, 1961. 
entretempo o embaixador agradeceu a janta oferecida pela família, convidou-os a participarem da "festa de chegada". E ao sair para a jornada do dia cantou:

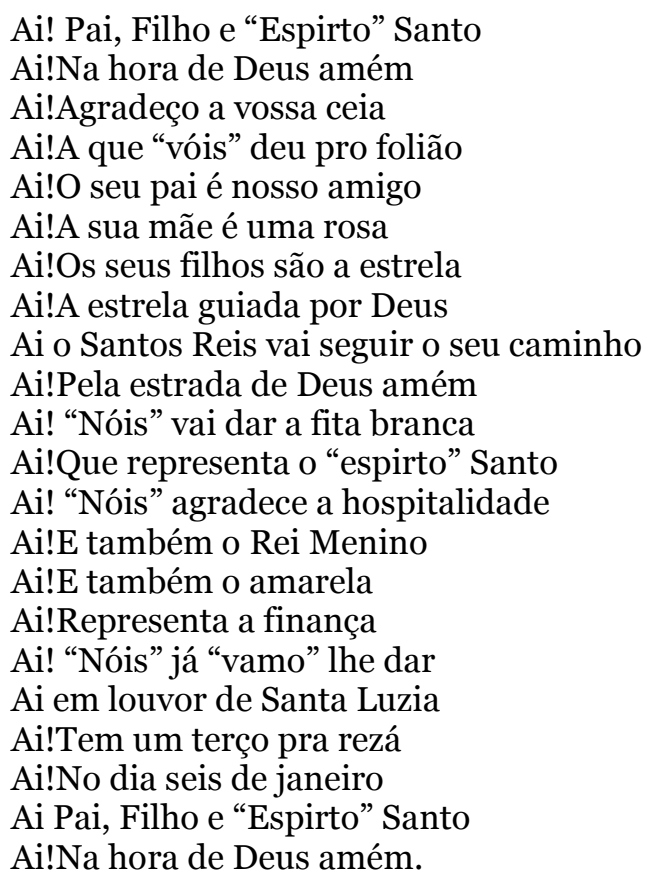

Estruturalmente o rito da Folia de Reis é repetitivo no seu desenvolvimento dentro das residências visitadas, as embaixadas são improvisadas dentro da situação que se desenvolve no interior da casa, porém, a estrutura da celebração só é alterada em casos especiais como na presença do presépio, em casas de pouso ou de foliões falecidos, ou quando o dono da residência como conhecedor do rito faz solicitações especiais à Companhia.

Esta espontaneidade na ação de troca entre os participantes do ritual, pode ser caracterizada por dois elementos importantes no desenvolvimento da jornada da Folia de Reis. Um elemento determinante e que promove o contrato com toda a estrutura ritualística, é que, tradicionalmente, as Companhias de Reis, são unidades autônomas independentes de outros grupos ou de uma organização sacerdotal. Esta forma estrutural centraliza na figura do embaixador a composição de seu universo simbólico e a subordinação dos demais a sua prática devocional. Pois o contrato entre todas as partes envolvidas com o ritual, que compõe o segundo elemento desta prática religiosa, é justamente o fato de ser uma troca simbólica entre homens, e entre homens e suas crenças (BRANDÃO, 1985) servindo a uma ordem simbólica que constitui um universo de fé muito próprio dos agentes envolvidos, nos quais os códigos de relação se legitimam dentro de um universo cultural que transcende a esfera 
religiosa, em um imaginário social mais amplo, comungado por todos os participantes.

As formas como se estabelece o contrato das residências entre os participantes segue uma lógica aparentemente simples entre as partes, na perspectiva de todos os participantes, o receber bem a bandeira, corresponde a afirmação de pertencimento a este universo através de amarras com as práticas simbólicas que estruturam o universo do culto aos Reis. Os devotos em sua maioria, sempre procuravam receber a bandeira da forma mais cordial possível, com lanches e refrigerantes, além de vastos momentos de conversas entre todos os envolvidos no ritual. Na perspectiva dos foliões, a bandeira é o ponto de contato entre os agentes envolvidos e o sagrado, um instrumento de mediação entre o desejo da graça e o próprio Deus, tendo em vista que esta no ato de celebração é a manifestação dos próprios Reis Santos cultuados pelos devotos. A sua devoção, se estabelece então através da hierofania manifesta no objeto de adoração. Os gestos religiosos são carregados de significados simbólicos, o beijar a bandeira, fazer o sinal da cruz ao recebê-la, enfeitá-la em homenagem aos santos, são expressões de uma forte religiosidade, uma linguagem, uma forma de manter comunicação com o divino. Dentre estes gestos, o mais significativo, que sintetiza este contrato entre santos e devotos, é o levar a bandeira para a benção dos cômodos, uma atitude de reverência diante do sagrado.

A representação que o embaixador Antonio Francisco tem sobre religião, tende a um diálogo entre as diversas concepções do "universo espiritual" -expressão muito usada por ele ao longo das entrevistas. Para este, a fé deve vir acompanhada de boas intenções. Assim, em sua jornada não há descriminação da residência que pode ou não receber a bandeira de Reis.

Esta representação que o mesmo tem acerca do universo religioso se caracteriza em um momento específico dentro de sua jornada. Em um dos muitos bairros visitados pela Companhia, esta entrou em um terreiro de umbanda, e foram saudar o altar do terreiro. Esta saudação exigiu do embaixador um jogo de versos que possibilitassem transitar pelos dois universos religiosos, saudando todos os santos do altar:

Ai!Aqui promessa chega pelo mensageiro

Ai!Com a espada de Ogum

Ai!Com a Santa Estrela Guia

Ai!E também Cosme e Damião 


\author{
Ai!Que ela é a nossa guia \\ Ai!Viva meu pai Jacó \\ Ai!E também minha mãe Sinhá \\ Ai!O altar que estou rezando \\ Ai!Iemanjá também está \\ Ai!Este terreiro é sagrado \\ Ai!Como todos os Orixá \\ Ai!Pai, Filho e Espírito Santo \\ Ai!E a lua ilumina \\ Ai!E também Santa Luzia \\ Ai!Ilumine esse terreiro \\ Ai!Pai, Filho e Espírito Santo \\ Ai!Já louvemo o seu altar.
}

De acordo com Brandão, o universo da religiosidade popular é um trânsito entre as circunstâncias da vida profana e as aspirações individuais dos agentes, em diálogo constante com o seu meio social. Esta perspectiva possibilita visualizar os versos acima, como um exercício de trânsito religioso e de afirmação do rito dentro de seu universo social.

Dos momentos diferenciados na jornada de Reis, a cantoria para finado, é um dos momentos que exige posturas diferenciadas de todos os participantes do ritual numa espécie de contrato que envolve a todos no espaço em um ambiente de "irmandade". ${ }^{16}$ Este se divide em duas partes: na primeira, o falecido é saudado pela Companhia com uma cantoria (ao longo dessa cantoria, pandeiro e caixa são silenciados), durante esta cantoria a pessoa que solicitou a saudação, se mantém de joelhos com a bandeira em mãos até o momento que o embaixador a mande levantar; a segunda parte, envolve uma oração coletiva, onde geralmente é rezado um Pai Nosso e uma Ave Maria em memória do falecido.

Das cantorias executadas ao longo da jornada, a que mais exige dos foliões uma postura ritualística diferenciada é a louvação de presépios. Ao entrarem nas residências, a Companhia é comunicada pelo dono da casa da localização do presépio, ou, como ocorreu muitas vezes, um dos componentes da Companhia fica encarregado de fazer essas observações nas visitas. A Companhia de Reis Santa Luzia, divide esta louvação em dois momentos, cantoria e o recital do embaixador. Mantendo a cantoria a sua estrutura habitual ao longo de toda a jornada, a saudação é preferencialmente executada em um recital do embaixador, em que este se aproxima do presépio saudando-o em versos que

16 Expressão usada pelo embaixador para definir união, companheirismo, comprometimento com a bandeira e com os foliões. 
em parte são repetidos em todas as ocasiões de louvação e versos que se constroem a partir da composição visual dos elementos representados na arrumação do mesmo e sua relação com as profecias do Antigo Testamento.

\section{Preparação}

A chegada da bandeira é o momento solene de toda a jornada ritual, pois esta representa para os participantes do ritual envolvidos, o cumprimento do crédito constituído entre os devotos e os santos, é a socialização da promessa. Neste sentido, esta se torna para o devoto, a firmação social de um contrato, e todos os presentes assumem o papel de reconhecer na ação do santos a sua condição divina, e em relação aos devotos beneficiados por alguma ação dos santos, como praticantes legitimadores de seu poder.

Para os foliões, o cumprimento da jornada representa a compreensão e concretização das profecias bíblicas contidas no Antigo Testamento, em que para estes, seriam os Três Reis Magos, os primeiros a crerem, e, com isso desprenderam uma jornada, que proclama o nascimento de Jesus. Esta é a estrutura básica do imaginário estruturador que é compartilhado por todos os participantes do ritual, que estabelecem entre si um compromisso, um contrato de partilha.

No local da chegada (um barracão comunitário) estavam concentradas aproximadamente pouco mais de cem pessoas, a grande maioria, de pessoas cujas casas foram visitadas pela Companhia ao longo da jornada, e vieram receber a bandeira, como contradom (BOURDIEU, 1999) da graça recebida. Estruturalmente, a chegada se divide em sete ciclos que se completam dentro da ação ritualística, firmando o contrato (ou contradom) entre as partes (santos e devotos): Consagração no primeiro arco (cantam as profecias que movem à bandeira); Consagração do segundo arco (cantam louvando ao nascimento do Menino Deus); Consagração do terceiro arco (consagram a bandeira); Em procissão para o altar, Companhia e foliões (pedidos e afirmações dos milagres dos santos); Reza do Terço; Corte das fitas; Festa.

\section{Rojões e violas}

A Companhia foi recebida pelos participantes do ritual com uma série de 
"Vivas", que os saudava. Diante do primeiro arco, logo procurou se posicionar em sua estrutura ritual de cantoria, ${ }^{17}$ mantendo a mesma organização no espaço, que usaram nas residências visitadas ao longo da jornada. O primeiro arco, diferentemente dos demais, foi saudado em duas etapas: na primeira, o embaixador recitou dezessete versos, saudando a estrela guia (representada no alto do em um recorte de papel metalizado dourado), narrando às profecias do nascimento e a simbologia que envolve os mistérios de sua bandeira; na segunda, a Companhia, saudou o arco cantando.

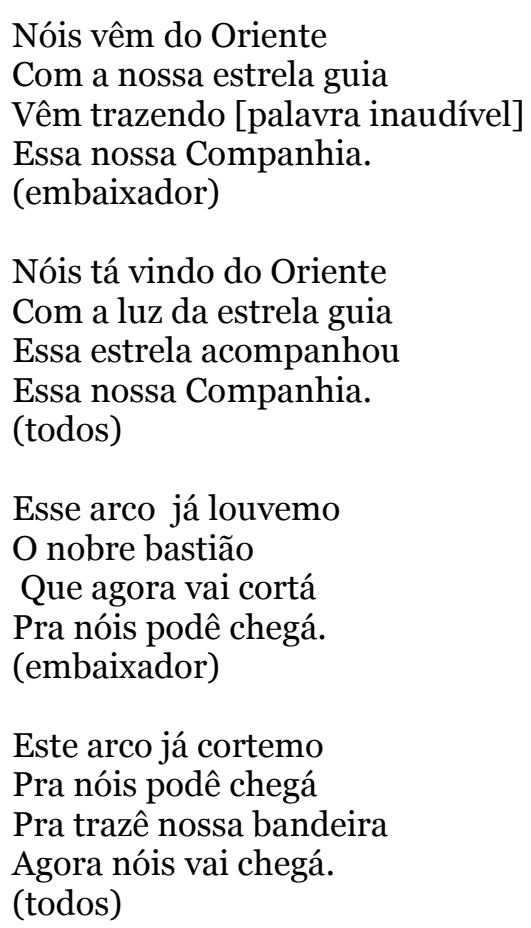

Recitadas as profecias e louvada a estrela, o Bastião cortou a "corrente" de papel crepom que envolvia o primeiro arco, e conduziu a Companhia -que seguiu tocando- para louvarem o segundo. Ao chegarem diante deste último o embaixador deu seqüência ao conjunto de versos que a exemplo do primeiro revelam em suas rimas, as passagens bíblicas acerca da genealogia da vida de Cristo contidas nos dois primeiros capítulos do Livro de São Mateus:

\footnotetext{
Este é o segundo arco

A chegada em Jerusalém

Até a [corte] do Rei Herodes

A estrela acompanhou.

(embaixador)

Cheguemos em Jerusalém
}

\footnotetext{
17 Posicionamento este que coloca em primeiro plano a bandeira da Companhia tendo o embaixador, o contramestre e o contrato logo em seguida, enquanto que os requintas e os instrumentistas de percussão se posicionam mais atrás.
} 

A chegada acompanhou Esse é o segundo arco Com a luz nóis já chegou. (todos)
E agora corta a corrente Que é a corrente da aliança Que todos nóis têm que fazê Para nóis podê chegá. (embaixador)
E agora corta a corente Pra chegá em vossa morada Ele é o Menino Deus Que a estrela acompanhou. (todos)

Repetindo o gesto do primeiro arco, o Bastião rompeu a "corrente" do segundo arco:

Este é o terceiro arco Que cheguemo com alegria Anunciando o nascimento Do Menino Salvador. (embaixador)

O arco do [segundo anjo] Que anunciou com alegria Anunciando o nascimento Do Menino Salvador. (todos)

Esta é a nossa missão E da Santa Estrela Guia Acompanhando a Companhia Nesta nossa romaria. (embaixador)

Com uma sarva de alegria Ao menino de Maria Nóis vem anunciando O nascimento de Jesus. (todos)

Meu irmão pode cortá Para nóis podê passá Pra chegá no nosso altar Pro terço nóis rezá. (embaixador)

Meu irmão pode cortá [trecho inaudível] Pra chegá no nosso altar Pro terço nóis rezá. (todos)

Nóis vimo e louvemo Essa nossa Companhia Vai chegá no nosso altar E um terço vai rezá. (embaixador) 


\author{
[trecho inaudível] \\ Vai chegá no nosso altar \\ E um terço vai rezá. \\ (todos) \\ [trecho inaudível] \\ Na hora de Deus amém \\ E da Santa Estrela Guia ${ }^{18}$. \\ (embaixador)
}

Rompido o terceiro arco, os Bastiões à frente da Companhia, passaram a dançar um jogo, que em seus gestos pareciam reproduzir uma luta, uma brincadeira com as espadas. Ainda diante do terceiro arco recém-aberto, antes de direcionar-se para o altar, a Companhia iniciou uma série de orações para os devotos ali presentes, iniciando a saudação a dois ex-foliões que ali estavam.

Feitas as cantorias e as orações, a bandeira passou a rumar a seu altar. À frente da Companhia que seguiu cantando, os dois Bastiões dançando, e gingando até chegarem diante do altar, no qual se ajoelharam novamente e retiraram as máscaras, para junto dos outros foliões, rezarem o terço da bandeira.

Diante do altar, a Companhia cantou às pessoas que estavam ali para cumprirem suas promessas e aos devotos que por um motivo ou outro, não puderam recebê-los em suas residências, mas vieram até o local de chegada para acompanhá-la e fazerem suas preces aos santos. O pouso da bandeira sobre o altar foi saudado com uma nova série de "vivas", que parecia refletir no espaço a satisfação de todos os presentes, ao verem que o contrato dos devotos fora cumprido com sucesso frente aos santos (pois este gesto praticamente findou a jornada). Este é no rito o momento de compartilhar coletivamente o contradom vivenciado por devotos a cumprirem suas promessas.

Ritualisticamente, este momento se revelou o de maior dinamicidade entre os participantes do ritual, pelo conjunto de ações espontâneas, que iam de simples "vivas" saudando os santos da bandeira, a beijos e pedidos dos devotos aos santos ali representados -o que não se repetiu ao longo do terço, que foi mais cadenciado e se desenvolveu dentro de uma orientação litúrgica católica das novenas, hierarquizando as manifestações de fé no tempo de sua execução.

Este comportamento ritualístico, coloca os santos como intercessores dos

18 O momento de chegada do terceiro arco foi acompanhado de perto por um número muito grande de pessoas, o que acabou prejudicando a captação do áudio dos dois últimos versos de saudação ao terceiro arco. 
devotos, porque pede pelas pessoas junto aos personagens da esfera celeste ou leva-lhes seus pedidos. Esta disposição do santo frente ao devoto transforma o universo simbólico da devoção, em uma relação de amizade, ou seja, o santo torna-se um amigo próximo dos que pedem, como dos que concedem, é por excelência um mediador, através do qual se forma uma cadeia de relações entre o Céu e a Terra (MENEZES, 2004). Na constituição desta ação devocional, houve um contrato afirmativo da manutenção desta relação entre devotos e santos diante do altar. Nas ações dos participantes, o pedir/agradecer/abençoar se manifestou dentro do espaço através de gestos corporais, cantorias e de falas dos devotos. Gestos, como aplausos, beijos e afagos à bandeira foram comuns entre os presentes, enquanto que, a participação destes se padronizava em orações esporádicas de Pai Nosso e Ave Maria ou como respostas a orações evocadas por algum membro da Companhia, que, entre uma cantoria para um devoto e outro, eram enunciadas.

Após este ciclo de cantorias a devotos, a Companhia iniciou a reza do terço. Orientados por um livro de novenas da Igreja Católica (O Terço da Família arquidiocese de Londrina), de onde extraíram os cânticos, e sob a orientação da reza do terço dos Reis Magos, do livro Histórias, Mensagens e Embaixadas de Folia de Reis, do embaixador da Companhia de Reis Mensageiros da Paz, Francisco Garbosi. Durante a reza, a espontaneidade de todos os participantes foi tomada por certa cadência, em que um dos foliões da Companhia, assim com no terço de saída da bandeira, assume a leitura dos mistérios.

Durante os cinco mistérios, estouraram-se rojões que demarcaram as passagens. O terço só foi dado por encerrado, com a Oração aos Santos Reis, uma oração de referência aos próprios Reis santos. Por volta das vinte horas, à extensa ladainha foi finalizada com um Pai Nosso e uma Ave Maria. Neste momento foram queimados alguns rojões que ainda restavam e os participantes do ritual se aproximaram da bandeira, alguns para retirarem os pedidos anexados à mesma e outros queriam apenas um pedaço das muitas fitas que na estrutura simbólica da Companhia representavam elementos da Sagrada Família e da própria Paixão de Cristo. Neste momento algumas pessoas que desde manhã estavam no salão comunitário trabalhando na decoração e limpeza, passaram a servir o lanche a todos os presentes (pão francês recheado com carne moída) e as bebidas. Após a distribuição das fitas aos devotos, a 
bandeira ficou repousada sobre seu altar, enquanto iniciava-se o baile, ao som de sanfona e dos violões da Companhia, os foliões e devotos dançaram até a entrada da madrugada da segunda-feira.

\section{Considerações finais}

O catolicismo tradicional popular brasileiro foi apresentado através da tradição de Folia de Reis. Uma tradição cultural-religiosa decorrente das raízes coloniais brasileira, viva e reconfigurada por uma literatura oral que imbrica em suas narrativas elementos que transitam entre os níveis culturais e religiosos eruditos e populares, mantendo-a viva no cotidiano formador de seus agentes produtores. Este aspecto da religiosidade popular (e não apenas do catolicismo) revela a natureza doméstica de seus "sacerdotes".

Ao nos reportarmos para este universo da fé, procuramos demonstrar em nossas observações como o rito de jornada, pouso e arremate na Folia de Reis, assim como a Companhia de Reis em si, se centraliza na figura de seu embaixador o papel de mediador que em versos estabelece o diálogo entre devotos, foliões e santos. Sendo a ação destes agentes a permanência de uma tradição que reflete a dimanicidade constitutiva da religiosidade popular.

\section{Bibliografia}

AMADO, Janaina e FERREIRA, Marieta M. (orgs.). Usos e abusos da história oral. [5 ${ }^{\mathrm{a}}$. edição]. Rio de Janeiro: Editora FGV, 2002.

BORGES, Célia Maia. Escravos e Libertos nas Irmandades do Rosário: devoção e solidariedade em Minas Gerais - séculos XVIII e XIX. Juiz de Fora: Editora UFJF, 2005.

BOURDIEU, Pierre. Marginalia: algumas notas adicionais sobre o dom. IN: Revista Mana, USP, São Paulo, vol. 2, nº. 2, 1996.

BRANDÃO, Carlos Rodrigues. Sacerdotes de viola: Os Rituais Religiosos do Catolicismo Popular em São Paulo e em Minas Gerais. Petrópolis: Vozes, 1981. . O que é folclore? São Paulo: Brasiliense, 1984.

Paulinas, 1985.

Memória do Sagrado: estudos de religião e ritual. São Paulo:

CASCUDO, Câmara Luis da. Dicionário do Folclore Brasileiro. São Paulo: Global, 2001. verbete Folia, pp. 242-243; e verbete Janeiras, p. 289.

. Antologia do Folclore Brasileiro [volume 1]. São Paulo, Global, 2003.

CASTRO, Zaïde Maciel de; COUTO, Aracy do Prado. Folia de Reis: Coleção 
Cidade do Rio de Janeiro. Rio de Janeiro: Editora Itambé, 1961.

COMBLIN, Pe. José. Para uma Tipologia do Catolicismo no Brasil. IN: Revista Eclesiástica Brasileira, vol. 28, fascículo 1, março de 1968.

ELIADE, Mircea. O Sagrado e o Profano - a essência da religiões. São Paulo: Martins Fontes, 2001.

GINZBURG, Carlo. O Queijo e os Vermes: o cotidiano e as idéias de um moleiro perseguido pela Inquisição. São Paulo: Cia. das Letras, 1987.

MENEZES, Renata de Castro. A Dinâmica do Sagrado: Rituais, Sociabilidade e Santidade num Convento do Rio de Janeiro. Rio de Janeiro: Relume Dumaré, Núcleo de Antropologia Política/UFRJ, 2004.

MORAIS FILHO, Alexandre José de Melo. Festas e Tradições Populares do Brasil. Rio de Janeiro: Edições de Ouro, 1946.

SZTOMPKA, Piotr. A Sociologia da mudança social. Rio de Janeiro: Civilização Brasileira, 1998.

TINHORÃO, José Ramos. Música Popular dos Índios, Negros e Mestiços. Petrópolis: Vozes, 1972.

Colaboração recebida em 16/10/2008 e aprovada em 16/02/2009. 